\title{
Effects of dietary Moringa oleifera leaf meal supplementation on chicken intestinal structure and growth performance
}

\author{
KAVOI, B. M. ${ }^{1}{ }^{*}$, GAKUYA, D. W. ${ }^{2}$, MBUGUA, P. N. ${ }^{3}$ and KIAMA, S. G. ${ }^{1}$ \\ ${ }^{1}$ Department of Veterinary Anatomy and Physiology, University of Nairobi, Riverside Drive, \\ P.O. Box 30197 00100, Nairobi, Kenya \\ ${ }^{2}$ Department of Clinical Studies, University of Nairobi, P.O. Box 29053 00625, Kangemi, Nairobi, Kenya \\ ${ }^{3}$ Department of Animal Production, University of Nairobi, P.O. Box 29053 00625, Kangemi, Nairobi, Kenya \\ *E-mail: drkanvo@yahoo.com
}

\begin{abstract}
Introduction: This study examined the effect of dietary Moringa oleifera leaf meal (MoLM) supplementation on intestinal structure vis-à-vis body weight gain in chickens. Materials and Methods: A total of 120-day-old Arbor Acres broiler chicks were randomly assigned to four groups, each with three replicates, 10 birds per replicate. Broiler feed supplemented with different quantities of MoLM, viz.: group T1 (control)- 0\%, T2- 7.5\%, T3- 15\% and T4- 30\%, was fed to the birds for 38 days, after which six birds/group were randomly selected and euthanized for histological work. Results: Normal histology was evident in the various intestinal components except the lamina propria and crypts in T4 and villus muscle strands in T3 and T4 where degenerative changes were observed. Villus height, crypt depth, muscle wall thickness and villus area in T1 (controls) were $935.6 \mu \mathrm{m}$, $173.8 \mu \mathrm{m}, 192.5 \mu \mathrm{m}$ and $0.19 \mathrm{~mm}^{-2}$, respectively. Relative to the controls, an increase in the afore mentioned measurements was noted in T2 $(6.4 \%, 8.4 \%, 10.6 \%$ and $10.5 \%$, respectively) while a reduction was recorded in T3 $(16.1 \%, 10.8 \%, 14.8 \%$ and $15.8 \%$, respectively) and T4 $(20.1 \%, 14.7 \%, 18.3 \%$ and $21.1 \%$, respectively). Body weight gain within the feeding period increased 31.2, 37.6, 23.9 and 10.9-fold in T1, T2, T3 and T4, respectively. Notably though, feed intake and villus height/ crypt depth ratio were not significantly different $(\mathrm{p}<0.05)$ between dietary treatments. Conclusion: Inclusion of M. oleifera in the diet should be done in moderation as quantities $\geq 15 \%$ interfere with intestinal structure and consequently body weight gain.
\end{abstract}

Keywords: broilers, gut, histology, leaf meal, M. oleifera.

\section{Introduction}

Moringa oleifera Lam. is one of the most widely distributed and naturalized species of the monogeneric family Moringaceae (RAMACHANDRAN, PETER and GOPALAKRISHNAN, 1980). It is a fast-growing drought-resistant tree whose morphological parts are an outstanding source of nutrients including protein, calcium, iron, vitamins and carotenoids (ANWAR, LATIF, ASHRAF et al., 2007). Indeed, the protein content of $M$. oleifera leaves, which Soliva, Kreuzer, Foidl et al. (2005) estimated at $32.1 \%$, is equivalent to that in many pulses (JOSHI and MEHTA, 2010). Thus, this plant has properties that make it a valuable dietary supplement for livestock as well as humans (MISHRA, SINGH and SINGH, 2012). In humans, leaves and pods of $M$. oleifera confer great nutritional benefits specially to malnourished individuals (FUGLIE, 2001). In spite of these many benefits, this plant is reported to contain anti-nutritional compounds (MAKKAR and BECKER, 1996, 1997) and to have genotoxic potential when consumed in large quantities (ASARE, GYAN, BUGYEI et al., 2012). Examples of anti-nutritional substances present in $M$. oleifera leaves are saponins, phytates and tannins (FERREIRA, FARIAS, OLIVEIRA et al., 2008). While saponins interfere with intestinal cell permeability (BAMISHAIYE, OLAYEMI, AWAGU et al., 2011), phytates chelate mineral ions, particularly $\mathrm{Zn}^{2+}$ and $\mathrm{Ca}^{2+}$, reducing their bioavailability (FERREIRA, FARIAS, OLIVEIRA et al., 2008). Tannins, on the other hand, bind proteins thereby interfering with protein digestibility (WALLACE, OLESZEK, FRANZ et al., 2010).

In chickens, the leaf meal of $M$. oleifera is well consumed and growth rate monitoring is easy to carry out. The chicken small intestine, which consists of duodenum, jejunum and ileum, plays a significant role in the final phase of nutrient digestion and absorption (INCHAROEN, YAMAUCHI, ERIKAWA et al., 2010). The jejunum is the largest of the three segments and is where maximum digestion and absorption takes place (NASRIN, SIDDIQI, MASUM et al., 2012). Moreover, diet-induced alterations in intestinal structure are most profound in this segment (UNI, GANOT and SKLAN, 1998). In a study by Gabella (1985), the wall of the chicken small intestine was described as having four directly apposed smooth muscle layers namely, inner longitudinal layer, inner circular layer, outer circular layer and outer longitudinal layer. This author reports no layer of connective tissue equivalent to the submucosa of mammals. The intestinal mucosa is thrown into villi which are lined by a single layer of absorptive cells (the enterocytes) studded with mucus- secreting goblet cells (FISININ and SURAI, 2013). The intestinal crypts, which lie in the lamina propria, are the sites for differentiation of the enterocytes, goblet cells, enteroendocrine cells and Paneth cells (the latter cell type is still poorly studied in birds) (PORTER, BEVINS, GHOSH et al., 2002). 
Diet composition can alter gut structure and consequently its absorptive capacity and animal performance (HAMEDI, REZAIAN and SHOMALI, 2011). Previously, changes in gut structure have been reported in birds fed diets of different types and composition including methylated citrus (LANGHOUT, SCHUTTE, VAN LEEUWEN et al., 1999), lupine seeds (OLKOWSKI, CLASSEN, WOJNAROWICZ et al., 2005), bamboo charcoal (RUTTANAVUT, YAMAUCHI, GOTO et al., 2009) and fermented ginger (INCHAROEN and YAMAUCHI, 2009). Although research surrounding $M$. oleifera adequately elucidates its impact (when fed to animals) on digestibility (SANCHEZ, SPORNDLY and LEDIN, 2006; GAKUYA, MBUGUA, KAVOI et al., 2014) and GIT organ sizes (BERGER, HABS, JAHN et al., 1984; NKUKWANA, MUCHENJE, PIETERSE et al., 2004), data on the microscopic alterations produced on the gut by this plant are scanty. In the current work, small intestines of broiler chickens fed MoLM at $0 \%, 7.5 \%, 15 \%$ and $30 \%$ for 38 days were analyzed histologically and histomorphometrically in an attempt to elucidate to what extent the different quantities of MoLM interfere with intestinal structure. Additionally in this study, data on body weight gain and feed consumption are provided.

\section{Materials and Methods}

\subsection{Birds and housing}

A total of 120-day-old Arbor Acres broiler chicks were purchased from the hatcheries of Kenchic Limited (Nairobi, Kenya) and transported to the Department of Animal Production, University of Nairobi. Here, the chicks were raised under conditions of 12L:12D photoperiod (06:00-18:00hr) and a temperature-controlled room. Commercial broiler starter was fed to the birds before being introduced to experimental diets on the third day. Feed and fresh water were offered ad libitum and vaccines were given appropriately. On day three, the 120 chicks were weighed and randomly allotted to four groups designated T1, T2, T3 and T4, each having three replicates, 10 birds per replicate. Each replicate was accommodated in its own cage. All protocols for this research were approved by the Ethics Committee for Animal Care and Use of the University of Nairobi.

\subsection{Acquisition, formulation and administration of experimental diets}

Leaves of the M. oleifera plant were obtained from farmers in Mutito- Andei division of Makueni County, Kenya. The leaves were harvested green from branches of mature trees after which they were air-dried under shade and with constant turning over to avert fungal growth (MISHRA, SINGH and SINGH, 2012). After 7 days of drying, the leaves were ground into a fine powder (MoLM) using an electric blender. The leaf meal was then tightly packaged in polythene bags and kept at room temperature until required. Ground maize, omena, soybeans, wheat pollard, limestone, cattle salt, broiler premixes, methionine and lysine were purchased from reliable feed manufacturers and delivered to the department of Animal Production where broiler starter and later broiler finisher diets were formulated and the MoLM incorporated at $0 \%, 7.5 \%, 15 \% \& 30 \%$ for groups T1 (control), T2, T3 \& $\mathrm{T} 4$, respectively. Chicks in each group had free access to the appropriate diets for the 38-day period, after which they were weighed and sacrificed for histological studies.

\subsection{Tissue fixation and harvesting}

Six birds per group (two from each replicate cage) were, at the end of the feeding period, randomly selected and euthanized by electrical stunning at $70 \mathrm{~V}$ followed by cervical dislocation (NKUKWANA, MUCHENJE, PIETERSE et al., 2014). The body of the chicken was opened up to allow perfusion fixation, which was done via the heart with $10 \%$ formaldehyde. The jejunum was then identified as detailed in (INCHAROEN, YAMAUCHI, ERIKAWA et al., 2010). A five-centimeter length of the mid jejunal region was tied with a thread at both ends and injected with the same fixative without causing distension. The ligated segment was then dissected out and transversally cut into small pieces, which were fixed further by immersion using the same fixative. Subsequently, pieces for microscopy were selected by systematic random sampling.

\subsection{Histological procedure}

Tissue pieces were dehydrated in increasing concentrations of ethanol $(70 \%, 80 \%, 95 \%$ and twice in $100 \%)$ and cleared using xylene. The tissues were then infiltrated and embedded in paraffin wax. Using a rotary microtome (Leitz Wetzlar, Germany), five-micrometer-thick transverse sections were cut from the wax blocks, placed on glass slides and stained with $H \& E$.

\subsection{Histomorphometric analysis}

Quantitative data related to villus height, villus breadth at basal and apical parts, crypt depth, apparent villus area, and villus height/crypt depth ratio were analyzed from $H \& E$ micrographs. Sampling of the tissues for histomorphometry was done following our earlier protocol (KAVOI, MAKANYA, PLENDL et al., 2012). Thus, for each dietary treatment group, wax blocks were prepared from tissues selected randomly from at least six birds. Ten to fifteen micrographs were prepared from each block and analysis of the various intestinal parameters carried out on 30-35 randomly generated test fields using an image analyzer (Nikon Cosmozone 1S, Nikon, Japan).

The exact jejunal regions on which measurements were taken are illustrated in Figure 1. Villus height was estimated as the distance between the villus tip and base, excluding the intestinal crypt, while villus breadth was measured at the basal and apical regions of the villus. Crypt depth was measured from the most basal to the most apical part of the crypt. Apparent villus area was estimated by trigonometry from villus height, villus breadth at base and villus breadth at apical region (IJI, SAKI and TIVEY, 2001). Thus, where apical villus breadth is denoted by $a$, basal villus breadth by $b$ and villus height by $h$, the apparent area of the villus (AV) was worked out as follows:

$\mathrm{AV}=[(\mathrm{b}+\mathrm{a}) / 2] \times \mathrm{h}$

\subsection{Data analysis}

Quantitative data between control and M. oleifera-treated birds were compared using the Student's $t$-test. Differences were considered to be significant at $\mathrm{p}<0.05$. In all cases, data were presented as mean \pm SD. 


\section{Results}

\subsection{Histological observations}

Intestinal crypts of birds fed with different quantities of MoLM are shown in Figure 2. The lamina propria, in which the crypts are located, was structurally normal in T1, T2 and T3 but degenerative changes are evident in T4 (Figure 2).

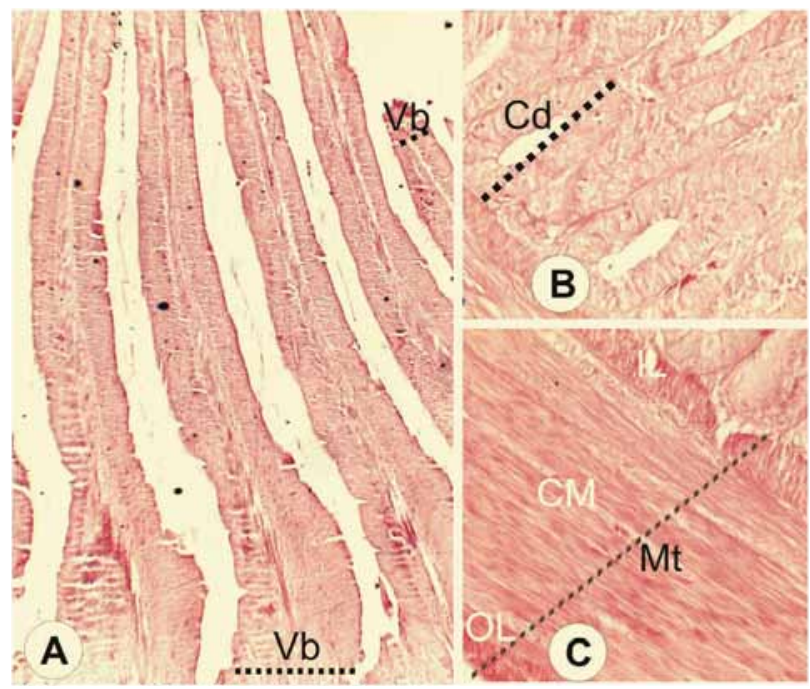

Figure 1. Micrographs taken from Tl to show the exact regions of the intestine from which measurements were performed. (A) Villi breadths $(\mathrm{Vb})$ were taken from the basal and apical regions of the villi (B) Crypt depth $(\mathrm{Cd})$ was measured from the extreme ends of the basal and apical regions $(\mathbf{C})$ Muscle wall thickness measurements incorporated the inner layer (IL) and outer layer (OL) of longitudinal muscle and circular muscle (CM).
A higher magnification of the crypts is shown in Figure 3. While the crypts appeared structurally normal in T1, T2 and T3, degenerative changes were noted in the crypts of T4. Goblet and mitotic cells were clearly discerned in $\mathrm{T} 1$ and $\mathrm{T} 2$, less clear in T3 and missing in T4 (Figure 3 ).

Figure 4 demonstrates the smooth muscle strands in the villus core. The muscle fibers were of normal structure in $\mathrm{Tl}$, where they presented well-formed long continuous bands. In T2, the muscle bands were broken into short strands while in $\mathrm{T} 3$ and $\mathrm{T} 4$, the bands showed evidence degeneration (Figure 4).

\subsection{Histomorphometry}

Data on the impact of MoLM on villus height, basal and apical villus breadths, and crypt depth and muscle wall thickness are presented in Table 1. The height of the villus, which was $935.6 \pm 103.4 \mu \mathrm{m}$ in the $\mathrm{Tl}$ (controls) increased by $6.4 \%$ in $\mathrm{T} 2$ while decreasing by $16.1 \%$ and $20.1 \%$ in $\mathrm{T} 3$ and T4, respectively. The villus breadth at the base in $\mathrm{Tl}$ was $187.6 \pm 44.6 \mu \mathrm{m}$, a value which increased by $4.8 \%$ in $\mathrm{T} 2$ and decreased by $23.6 \%$ in T3 and $31.3 \%$ in T4. The crypt depth in Tl was estimated at $173.8 \pm 54.3 \mu \mathrm{m}$ and this value increased by $8.4 \%$ in $\mathrm{T} 2$ while decreasing by $10.8 \%$ in $\mathrm{T} 3$ and $14.7 \%$ in in $\mathrm{T} 4$. Intestinal wall thickness, which measured $192.5 \pm 26.6 \mu \mathrm{m}$ in $\mathrm{T} 1$, showed an increase of $10.6 \%$ in $\mathrm{T} 2$ and a decrease of $14.8 \%$ in $\mathrm{T} 3$ and $18.3 \%$ in $\mathrm{T} 4$. Villus area in Tl was $0.19 \pm 0.02 \mathrm{~mm}^{-2}$ and this measurement increased by $10.5 \%$ in $\mathrm{T} 2$ while reducing by $15.8 \%$ and $21.1 \%$ in $\mathrm{T} 3$ and $\mathrm{T} 4$, respectively. No significant differences $(\mathrm{p}<0.09)$ villus height / crypt depth ratio were noted between controls (5.2 \pm 0.6$)$ as compared with the MoLM-treated birds (5.1 \pm 0.5 in $\mathrm{T} 2,4.9 \pm 0.7$ in $\mathrm{T} 3$ and $5.0 \pm 0.6$ in $\mathrm{T} 4)$.


Figure 2. Histological sections of intestinal crypts in T1, T2, T3 and T4. The lamina propria surrounding the crypts appears structurally intact in T1, T2 \& T3. Degenerative changes (arrows) are observed in the lamina propria in T4. Notice the inner longitudinal muscle layer (ILM) which lies adjacent to the crypt bases. Bar= $50 \mu \mathrm{m}$. 


\subsection{Feed intake and body weight gain}

Table 2 shows body weight gain (g/bird) at the start and at the end of dietary treatment and the feed intake ( $\mathrm{g} / \mathrm{bird} / \mathrm{day})$. Body weight gain within the feeding period increased 31.2, 37.6, 23.9 and 10.9-fold in T1, T2, T3 and T4, respectively. Feed consumption in controls (98.2 \pm 17.6$)$ was not significantly

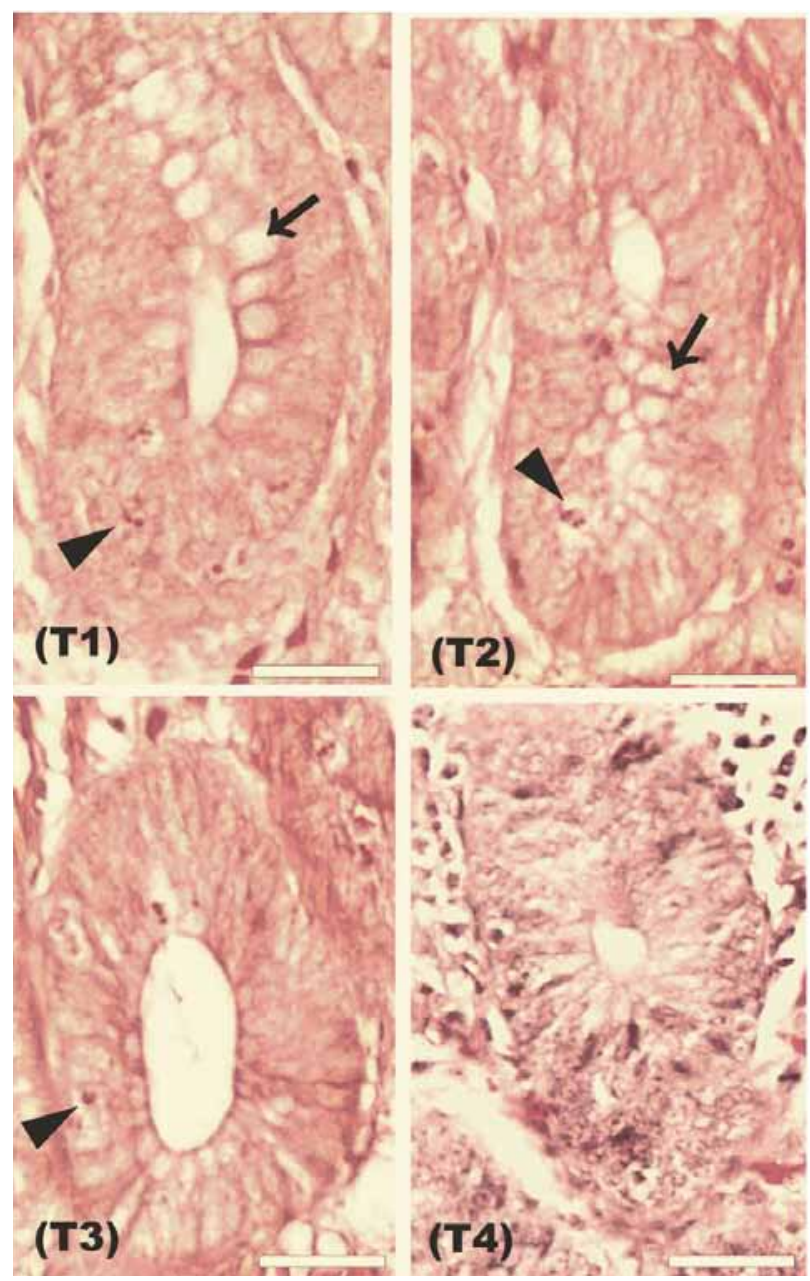

Figure 3. Histomicrographs of intestinal crypts in T1, T2, T3 and $\mathrm{T} 4$. The crypts are structurally normal in all groups except $\mathrm{T} 4$ where degeneration changes are observed. Cell mitosis (arrow heads) and goblet cells (arrows) are observed in $\mathrm{T} 1$ and $\mathrm{T} 2$. In T3, only the mitotic cells are discernible while in $\mathrm{T} 4$ both cell types are missing. Bar $=25 \mu \mathrm{m}$. different $(\mathrm{p}<0.05)$ from the treated groups $(95.6 \pm 13.1$ in $\mathrm{T} 2$, $81.6 \pm 12.2$ in $\mathrm{T} 3$ and $88.3 \pm 11.9$ in $\mathrm{T} 4)$.

\section{Discussion}

In the current investigation, alterations in intestinal histology and histomorphometry were demonstrated in chickens whose diet was supplemented with MoLM at quantities $\geq 15 \%$. A study by Nkukwana, Muchenje, Pieterse et al. (2014) showed that supplementation of MoLM at $25 \mathrm{~g} / \mathrm{kg}$ of chicken feed $(2.5 \%) \mathrm{did}$ not impair the efficiency of nutrient utilization, but enhanced body weight gain in the birds. In rats (ADEDAPO, MOGBOJURI and EMIKPE, 2009), oral administration of aqueous leaf extracts of $M$. oleifera at 400,800 and $1600 \mathrm{mg} / \mathrm{kg}$ produced a dose dependent reduction in body weight gain, which the authors attributed to possible pathologies in the gut. Studies done on several other species including pigs (MEKBUNGWAN, YAMAUCHI and THONGWITTAYA, 2003) and ducks (KHAMBUALAI, RUTTANAVUT, KITABATAKE et al., 2009) revealed that diet composition affects gut structure. The absorptive capacity of the gut and therefore body weight gain are adversely affected by diet-induced changes in gut morphology (HAMEDI, REZAIAN and SHOMALI, 2011). This is of particular interest in broiler chicken rearing where body weight gain is of great economic concern.

On villus structure, our findings were that villus heights, villus breadths, crypt depths and villus area decreased significantly when MoLM amounts $\geq 15 \%$ was included in the chicken diet, whilst villus height/crypt depth ratio remains unchanged. The thickness of the intestinal muscle wall was also noted to decrease significantly when a similar was added to the chicken feed. A study by Awad, Böhm, Razzazi-Fazeli et al. (2006), suggests a direct correlation between villus area and the surface area available for nutrient absorption. Villus length/crypt depth ratio is a key determinant of the functional capacity of the intestine and as such, a decrease in this ratio is considered deleterious to digestion and absorption of nutrients (PLUSKE, HAMPSONAND and WILLIAMS, 1997). Similar importance is also attached to the intestinal muscle wall, whose activity produces local movement and folding of the mucosa to enhance contact between the epithelium and luminal contents for purposes of absorption (BURKITT, YOUNG and HEATH, 1993). In a study by Hamedi, Rezaian and Shomali (2011) feeding of chicken with sun flower meal was caused a marked reduction in villus length/ crypt depth ratio, which the author attributed to villus atrophy induced by the high fiber content in the meal. Although villus atrophy appears to be a likely reason for the villus height and breadth reduction noted in the

Table 1. Mean values ( \pm SD given in parenthesis) of villi height, basal villi breadth, crypt depth, intestinal muscle thickness (in $\mu$ m), villus area $\left(\mathrm{mm}^{-2}\right)$ and villus height/ crypt depth ratio in birds fed M. oleifera leaf meal (MoLM) at 0\% (T1), 7.5\% (T2), 15\% (T3) and $30 \%(\mathrm{~T} 4)$.

\begin{tabular}{lcccc}
\hline \multicolumn{1}{c}{ Parameter } & T1 & T2 & T3 & T4 \\
\hline Villi height $(\mu \mathrm{m})$ & $935.6(103.4)$ & $995.5(110.7)$ & $784.9(92.2)$ & $747.5(105.9)$ \\
Villi breath, base $(\mu \mathrm{m})$ & $187.6(44.6)$ & $196.7(38.2)$ & $143.4(41.7)$ & $128.8(33.8)$ \\
Crypt depth $(\mu \mathrm{m})$ & $173.8(54.3)$ & $188.4(47.6)$ & $155.0(44.2)$ & $148.3(41.7)$ \\
Muscle wall thickness $(\mu \mathrm{m})$ & $192.5(26.6)$ & $212.9(23.4)$ & $164.0(27.0)$ & $157.3(24.3)$ \\
Villus area $\left(\mathrm{mm}^{-2}\right)$ & $0.19(0.02)$ & $0.21(0.03)$ & $0.16(0.01)$ & $0.15(0.02)$ \\
Villus height $/$ crypt depth ratio & $5.2(0.6)$ & $5.1(0.5)$ & $4.9(0.7)$ & $5.0(0.6)$ \\
\hline
\end{tabular}

$\%$ decrease or increase $=[($ Difference in mean between $\mathrm{Tl} \&$ other group $) /$ Mean in Tl $] \times 100$. 

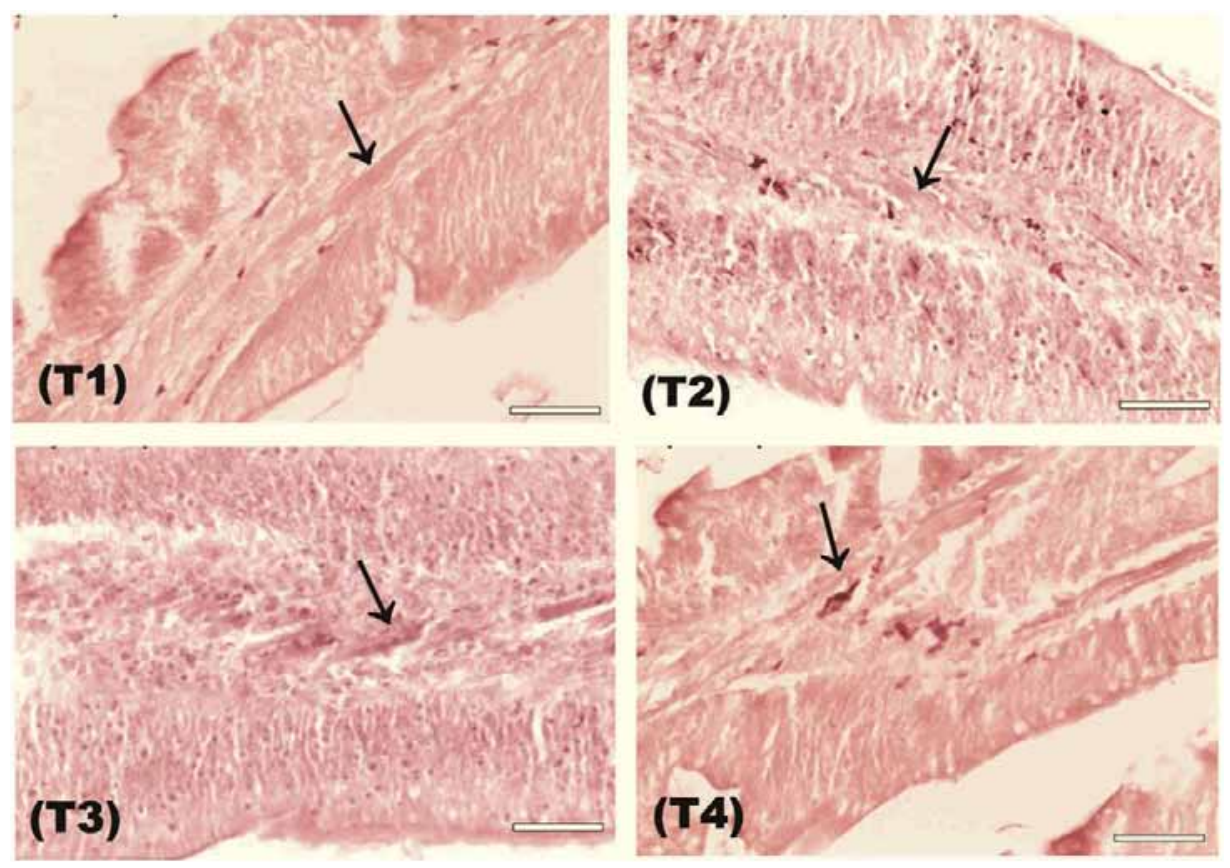

Figure 4. Sections of intestinal villi cut along their lengths to show the bands of smooth muscles in their cores in T1, T2, T3 and T4. The muscles in T1 are structurally intact appearing as long continuous bands. In T2 the bands are discontinuous while in T3 \& T4, degenerative changes are well discerned. Bar $=50 \mu \mathrm{m}$.

Table 2. Mean values ( \pm SD given in parenthesis) of body weights $(\mathrm{g} / \mathrm{bird})$ on days 0 and 38 and of feed intake (g/bird/day) in birds fed M. oleifera leaf meal (MoLM) at $0 \%$ (T1), 7.5\% (T2), 15\% (T3) and 30\% (T4).

\begin{tabular}{lcccc}
\hline \multicolumn{1}{c}{ Parameter } & T1 & T2 & T3 & T4 \\
\hline Feed intake (g/ bird/ day) & $98.2(17.6)$ & $95.6(13.1)$ & $81.6(12.2)$ & $88.3(11.9)$ \\
Body weight (g/ bird), day 0 & $48.6(6.6)$ & $50.1(6.2)$ & $49.4(7.1)$ & $50.8(6.8)$ \\
Body weight (g/ bird), day 38 & $1516(104.2)$ & $1883.8(103.6)$ & $1181(86.7)$ & $553(67.1)$ \\
Growth ratio & 31.2 & 37.6 & 23.9 & 10.9 \\
\hline
\end{tabular}

Growth ratio $=$ mean weight at day $38 /$ mean weight at day 0 (KAVOI, MAKANYA, PLENDL et al., 2012).

current study, the magnitude of such atrophy might not have been high enough to alter the villus height/ crypt depth ratio.

Cells proliferating by mitosis in the crypt differentiate as they migrate upward to the villus and reach the villus tip where they are extruded into the intestinal lumen (Potten 1998). Thus, mitotic cells housed in the crypts constantly replenish epithelial cells, including enterocytes and goblet cells (POTTEN and GRANT, 1998). Our observations suggest that components in MoLM disrupt mitotic activity within the crypts resulting in lack of epithelial cell replacement, this therefore being a likely reason for the absence of the mitotic cells in T4 and of the goblet cell in T3 and T4. Furthermore, deepening of the crypt and lengthening of the villus cannot take place in absence of activated cell mitosis (ONDERCI, SAHIN, SAHIN et al., 2006).

Degenerative changes are observed in the lamina propria and crypts of T4, and in the villus muscle strands of T3 and T4. Epithelial cells lining the villus, especially those located at the villus tip, are sensitively affected by nutritional content (INCHAROEN, YAMAUCHI, ERIKAWA et al., 2010). In a study by Olugbemi, Mutayoba and Lekule (2010) in which MoLM inclusion in the diet exceeded 5\%, decreased feed utilization efficiency and sub-optimal growth performance were demonstrated, with no reports on intestinal structure.
M. oleifera leaves contain phytates and tannins, which have the capacity to depress protein digestibility as well as intestinal absorption of dietary nutrients (MOYO, MASIKA, HUGO et al., 2011). Phytosterols are other anti-nutrient substances found in M. oleifera leaves and in seeds of the pea plant (SINGH, 1988). Shortening of intestinal villi and reduced weight gain occurred in piglets fed raw pea seed meal (MEKBUNGWAN and YAMAUCHI, 2004) suggesting that anti-nutrient constituents in the pea seeds were responsible for these changes. Going by these reports, it can be argued that similar compounds in MoLM account for the reduction in villus size, muscle wall thickness and the degeneration noted in the lamina propria and villi. Presumably, the MoLM-induced distortions in intestinal structure may be the reason for the reduced body weight gain in T3 and T4.

In previous articles, authors present contradictory data concerning the quantities of anti-nutritional compounds in M. oleifera leaves. Makkar and Becker (1997) estimated the quantities of tannin at $1.2 \%$ and phytates at $2.1 \%$ while in other studies (BAMISHAIYE, OLAYEMI, AWAGU et al., 2011), a composition of $2.6 \%$ phytates and $1.6 \%$ saponins are reported. The discrepancy in these values may be explained by the fact that the quantities of various $M$. oleifera leaf constituents is determined by several factors including agro-climatic conditions 
(SIDDHURAJU and BECKER, 2003), season (IQBAL and BHANGER, 2006) and age of the tree (D'SOUZA and KULKARNI, 1993). A paper by Ferreira, Farias, Oliveira et al. (2008) reports phytate composition of $1 \%-6 \%$ as capable of reducing bioavailability of minerals in monogastric animals. Tannins are a complex group of water soluble polyphenolic plant metabolites, which, at levels as low as $0.05 \mathrm{mg} / \mathrm{ml}$ reduces enzyme mediated hydrolytic reactions $(\mathrm{HE}, \mathrm{LV}$ and YAO, 2006). In the present study, the chicken feed was supplemented with MoLM amounts as high as 30\% and for a fairly long period of time ( 38 days) and the leaves used were from fully mature plants growing in a hot dry environment. Plausibly, the content of anti-nutritional compounds in the $M$. oleifera leaves would have been high enough to induce the observed intestinal changes.

\section{Conclusion}

We conclude that dietary MoLM supplementation at levels $\geq 15 \%$ impacts negatively on intestinal structure and consequently body weight gain in chickens. This should be kept in mind when using this plant to formulate feed for poultry. Given that ingredients that impair digestive function have been isolated from the $M$. oleifera leaves, it is highly likely that the observed intestinal histological changes are attributed to such ingredients. M. oleifera is a widely valued dietary supplement for livestock and humans. Accordingly, data regarding how consumption of this plant affects gut structure, which this study provides, are paramount. Future studies should confirm the quantities of anti-nutritional substances in the MoLM portions used in this study and how long it would take the birds to regain normal intestinal structure on withdrawing the MoLM from the diet.

Acknowledgements: We thank Carnegie- RISE AFNNET project on Natural Products Training Network for funding this study and the staff in the departments of Animal Production and Veterinary Anatomy and Physiology for their excellent technical assistance.

\section{References}

ADEDAPO, AA., MOGBOJURI, OM. and EMIKPE, BO. Safety evaluations of the aqueous extract of the leaves of Moringa oleifera in rats. Journal of Medicinal Plants Research, 2009, vol. 3, n. 8, p. 586-591.

ANWAR, F., LATIF, S., ASHRAF, M. and GILANI, AH. Moringa oleifera: a food plant with multiple medicinal uses. Phytotherapy Research, 2007, vol. 21, n. 1, p. 17-25. PMid:17089328. http:// dx.doi.org/10.1002/ptr.2023.

ASARE, GA., GYAN, B., BUGYEI, K., ADJEI, S., MAHAMA, R., ADDO, P., OTU-NYARKO, L., WIREDU, EK. and NYARKO, A. Toxicity potentials of the nutraceutical Moringa oleifera at suprasupplementation levels. Journal of Ethnopharmacology, 2012, vol. 139, n. 1, p. 265-272. PMid:22101359. http://dx.doi.org/10.1016/j. jep.2011.11.009.

AWAD, WA., BÖHM, J., RAZZAZI-FAZELI, E., GHAREEB, K. and ZENTEK, J. Effect of addition of a probiotic microorganism to broiler diets contaminated with deoxynivalenol on performance and histological alterations of intestinal villi of broiler chickens. Poultry Science, 2006, vol. 85, n. 6, p. 974-979. PMid:16776464. http:// dx.doi.org/10.1093/ps/85.6.974.

BAMISHAIYE, EI., OLAYEMI, FF., AWAGU, EF. and BAMSHAIYE, OM. Proximate and phytochemical composition of Moringa oleifera leaves at three stages of maturation. Advance Journal of Food Science and Technology, 2011, vol. 3, n. 4, p. 233-237.

BERGER, MR., HABS, M., JAHN, SA. and SCHMAHL, D. Toxicological assessment of seeds from Moringa oleifera and Moringa stenopetala, two highly efficient primary coagulants for domestic water treatment of tropical raw waters. East African Medical Journal, 1984, vol. 61, n. 9, p. 712-716. PMid:6535725.

BURKITT, HG., YOUNG, B. and HEATH, JW. Wheater's functional histology: a textbook and color atlas. 3rd ed. Edinburgh: Churchill Livingstone, 1993. $260 \mathrm{p}$.

D'SOUZA, J. and KULKARNI, AR. Comparative studies on nutritive values of tender foliage of seedlings and mature plants of Moringa oleifera Lam. Journal of Economic and Taxonomic Botany, 1993, vol. 17, n. 2 , p. $479-485$.

FERREIRA, PMP., FARIAS, DP., OLIVEIRA, JT. and CARVALHO, FU. Moringa oleifera: bioactive compounds and nutritional potential. British Journal of Nutrition, 2008, vol. 21, n. 4, p. 5-51.

FISININ, VI. and SURAI, P. Gut immunity in birds: facts and reflections (review). Sel'skokhozyaistvennaya Biologiya [Agricultural Biology], 2013, n. 4, p. 3-25. http://dx.doi.org/10.15389/agrobiology.2013.4.3eng.

FUGLIE, LJ. The miracle tree: Moringa oleifera: natural nutrition for the tropics. training manual. Dakar, Senegal: Church World Service, 2001.

GABELLA, G. Structure of the musculature of the chicken small intestine. Anatomy and Embryology, 1985, vol. 171, n. 2, p. 139149. PMid:3985363. http://dx.doi.org/10.1007/BF00341408.

GAKUYA, DW., MBUGUA, PN., KAVOI, B. and KIAMA, SG. Effect of supplementation of Moringa oleifera leaf meal in broiler chicken feed. International Journal of Poultry Science, 2014, vol. 13, n. 4, p. 208-213. http://dx.doi.org/10.3923/ijps.2014.208.213.

HAMEDI, S., REZAIAN, M. and SHOMALI, T. Histological changes of small intestinal mucosa of cocks due to sunflower meal single feeding. American Journal of Animal and Veterinary Sciences, 2011, vol. 6, n. 4, p. 171-175. http://dx.doi.org/10.3844/ajavsp.2011.171.175.

HE, Q., LV, Y. and YAO, K. Effects of tea polyphenols on the activities of a-amylase, pepsin, trypsin and lipase. Food Chemistry, 2006, vol. 101, n. 3, p. 1178-1182. http://dx.doi.org/10.1016/j. foodchem.2006.03.020.

IJI, PA., SAKI, A. and TIVEY, DR. Body and intestinal growth of broiler chicks on a commercial starter diet. 1. Intestinal weight and mucosal development. British Poultry Science, 2001, vol. 42, n. 4, p. 505-513. PMid:11572627. http://dx.doi.org/10.1080/00071660120073151.

INCHAROEN, T. and YAMAUCHI, K. Production performance, egg quality and intestinal histology in laying hens fed dietary dried fermented ginger. International Journal of Poultry Science, 2009, vol. 8, n. 11, p. 1078-1085. http://dx.doi.org/10.3923/ijps.2009.1078.1085.

INCHAROEN, T., YAMAUCHI, K., ERIKAWA, T. and GOTOH, H. Histology of intestinal villi and epithelial cells in chickens fed low-crude protein or low-crude fat diets. Italian Journal of Animal Science, 2010, vol. 9, n. 82, p. 429-434.

IQBAL, S. and BHANGER, MI. Effect of season and production location on antioxidant activity of Moringa oleifera leaves grown in Pakistan. Journal of Food Composition and Analysis, 2006, vol. 19, n. 6-7, p. 544-551. http://dx.doi.org/10.1016/j.jfca.2005.05.001.

JOSHI, P. and MEHTA, D. Effect of dehydration on the nutritive value of drumstick leaves. Journal of Metabolomics and Systems Biology, 2010, vol. 1, n. 1, p. 5-9.

KAVOI, BM., MAKANYA, AN., PLENDL, J. and KIAMA, SG. Morphofunctional adaptations of the olfactory mucosa in postnatally developing rabbits. The Anatomical Record, 2012, vol. 295, n. 8, p. 1352-1363. PMid:22707244. http://dx.doi.org/10.1002/ar.22520. 
KHAMBUALAI, O., RUTTANAVUT, J., KITABATAKE, M., GOTO, H., ERIKAWA, T. and YAMAUCHI, K. Effects of dietary natural zeolite including plant extract on growth performance and intestinal histology in Aigamo ducks. British Poultry Science, 2009, vol. 50, n. 1, p. 123-130. PMid:19234936. http://dx.doi. org/10.1080/00071660802662788.

LANGHOUT, DJ., SCHUTTE, JB., VAN LEEUWEN, P., WIEBENGA, J. and TAMMINGA, S. Effect of dietary high- and low-methylated citrus pectin on the activity of the ileal microflora and morphology of the small intestinal wall of broiler chicks. British Poultry Science, 1999, vol. 40, n. 3, p. 340-347. PMid:10475630. http://dx.doi. org/10.1080/00071669987421.

MAKKAR, HPS. and BECKER, K. Nutritional value and anti-nutritional components of whole and ethanol extracted Moringa oleifera leaves. Animal Feed Science and Technology, 1996, vol. 63, n. 1-4, p. 211-228. http://dx.doi.org/10.1016/S0377-8401(96)01023-1.

MAKKAR, HPS. and BECKER, K. Nutrients and anti-quality factors in different morphological parts of the Moringa oleifera tree. The Journal of Agricultural Science, 1997, vol. 128, n. 3, p. 311-322. http://dx.doi.org/10.1017/S0021859697004292.

MEKBUNGWAN, A. and YAMAUCHI, K. Growth performance and histological intestinal alterations in piglets fed dietary raw and heated pigeon pea seed meal. Histology and Histopathology, 2004, vol. 19, n. 2, p. 381-389. PMid:15024699.

MEKBUNGWAN, A., YAMAUCHI, K. and THONGWITTAYA, N Histological alterations of intestinal villi in growing pigs fed soybean and pigeon pea seed meals. Canadian Journal of Animal Science, 2003, vol. 83, n. 4, p. 755-760. http://dx.doi.org/10.4141/A02-073.

MISHRA, SP., SINGH, P. and SINGH, S. Processing of Moringa oleifera leaves for human consumption. Bulletin of Environment, Pharmacology and Life Sciences, 2012, vol. 2, n. 1, p. 28-31.

MOYO, B., MASIKA, PJ., HUGO, A. and MUCHENJE, V. Nutritional characterization of Moringa (Moringa oleifera Lam.) leaves. African Journal of Biotechnology, 2011, vol. 10, n., p. 12925-12933.

NASRIN, M., SIDDIQI, MNH., MASUM, MA. and WARES, MA. Gross and histological studies of digestive tract of broilers during postnatal growth and development. Journal of the Bangladesh Agricultural University, 2012, vol. 10, n. 1, p. 69-77. http://dx.doi. org/10.3329/jbau.vl0il.12096.

NKUKWANA, TT., MUCHENJE, V., PIETERSE, E., MASIKA, PJ., MABUSELA, TP., HOFFMAN, LC. and DZAMA, K. Effect of Moringa oleifera leaf meal on growth performance, apparent digestibility, digestive organ size and carcass yield in broiler chickens. Livestock Science, 2014, vol. 161, p. 139-146. http://dx.doi.org/10.1016/j. livsci.2014.01.001.

OLKOWSKI, BI., CLASSEN, HL., WOJNAROWICZ, C. and OLKOWSKI, AA. Feeding high levels of lupine seeds to broiler chickens: plasma micronutrient status in the context of digesta viscosity and morphometric and ultrastructural changes in the gastrointestinal tract. Poultry Science, 2005, vol. 84, n. 11, p. 1707-1715. PMid:16463967. http://dx.doi.org/10.1093/ps/84.11.1707.

OLUGBEMI, TS. MUTAYOBA, SK. and LEKULE, FP. Effect of Moringa oleifera inclusion in cassava based diets fed to broiler chickens. International Journal of Poultry Science, 2010, vol. 9, n. 4, p. 363367. http://dx.doi.org/10.3923/ijps.2010.363.367.

ONDERCI, M., SAHIN, N., SAHIN, K., CIKIM, G., AYDÍN, A., OZERCAN, I. and AYDÍN, S. Efficacy of supplementation of alphaamylase-producing bacterial culture on the performance, nutrient use and gut morphology of broiler chickens fed a corn-based diet. Poultry
Science, 2006, vol. 85, n. 3, p. 505-510. PMid:16553283. http:// dx.doi.org/10.1093/ps/85.3.505.

PLUSKE, JR., HAMPSON, DJ. and WILLIAMS, IH. Factors influencing the structure and function of the small intestine in the weaned pig: a review. Livestock Production Science, 1997, vol. 51, n. 1-3, p. 215-236. http://dx.doi.org/10.1016/S0301-6226(97)00057-2.

PORTER, EM., BEVINS, CL., GHOSH, D. and GANZ, T. The multifaceted Paneth cell. Cellular and Molecular Life Sciences, 2002, vol. 59, n. 1, p. 156-170. PMid:11846026. http://dx.doi. org/10.1007/s00018-002-8412-z.

POTTEN, CS. Stem cells in gastrointestinal epithelium: numbers, characteristics and death. Philosophical Transactions of the Royal Society B: Biological Sciences, 1998, vol. 353, n. 1370, p. 821-830.

POTTEN, CS. and GRANT, HK. The relationship between ionizing radiation-induced apoptosis and stem cells in the small and large intestine. British Journal of Cancer, 1998, vol. 78, n. 8, p. 993-1003. PMid:9792141. http://dx.doi.org/10.1038/bjc.1998.618.

RAMACHANDRAN, C., PETER, KV. and GOPALAKRISHNAN, PK. PETER, KV. and GOPALAKRISHNAN, PK. Drumstick (Moringa oleifera): A multipurpose Indian vegetable. Economic Botany, 1980, vol. 34, n. 3, p. 276-283. http://dx.doi.org/10.1007/BF02858648.

RUTTANAVUT, J., YAMAUCHI, K., GOTO, H. and ERIKAWA, T. Effects of dietary bamboo charcoal powder including vinegar liquid on growth performance and histological intestinal change in Aigamo ducks. International Journal of Poultry Science, 2009, vol. 8, n. 3, p. 229-236. http://dx.doi.org/10.3923/ijps.2009.229.236.

SANCHEZ, NR., SPORNDLY, E. and LEDIN, I. Effect of feeding different levels of foliage of Moringa oleifera to Creole dairy cows on intake, digestibility, milk production and composition. Livestock Science, 2006, vol. 101, n. 1, p. 24-31.

SIDDHURAJU, P. and BECKER, K. Antioxidant properties of various solvent extracts of total phenolic constituents from three different agroclimatic origins of drumstick tree (Moringa oleifera Lam.) leaves. Journal of Agricultural and Food Chemistry, 2003, vol. 51, n. 8, p. 2144-2155. PMid:12670148. http://dx.doi.org/10.1021/jf020444+.

SINGH, U. Antinutritional factors of chick pea and pigeon pea and their removal by processing. Plant Foods for Human Nutrition, 1988, vol. 38, n. 3, p. 251-261. PMid:2467276. http://dx.doi. org/10.1007/BF01092864.

SOLIVA, CR., KREUZER, M., FOIDL, N., FOIDL, G., MACHMÜLLER, A. and HESS, HD. Feeding value of whole and extracted Moringa oleifera leaves for ruminants and their effects on ruminal fermentation in vitro. Animal Feed Science and Technology, 2005, vol. 118, n. 1-2, p. 47-62. http://dx.doi.org/10.1016/j. anifeedsci.2004.10.005.

UNI, Z., GANOT, S. and SKLAN, D. Post-hatch development of mucosal function in the broiler small intestine. Poultry Science, 1998, vol. 77, n. 1, p. 75-82. PMid:9469755. http://dx.doi.org/10.1093/ ps/77.1.75.

WALLACE, RJ., OLESZEK, W., FRANZ, C., HAHN, I., BASER, KH., MATHE, A. and TEICHMANN, K. Dietary plant bioactives for poultry health and productivity. British Poultry Science, 2010, vol. 51, n. 4, p. 461-487. PMid:20924841. http://dx.doi.org/10.1080 /00071668.2010.506908.

Received October 16, 2015 Accepted November 17, 2016 